\title{
Individual Differences in Learning and Remembering
}

\author{
Elfi Churnia ${ }^{1}$, Neviyarni Neviyarni ${ }^{2}$ \\ ${ }^{12}$ Universitas Negeri Padang
}

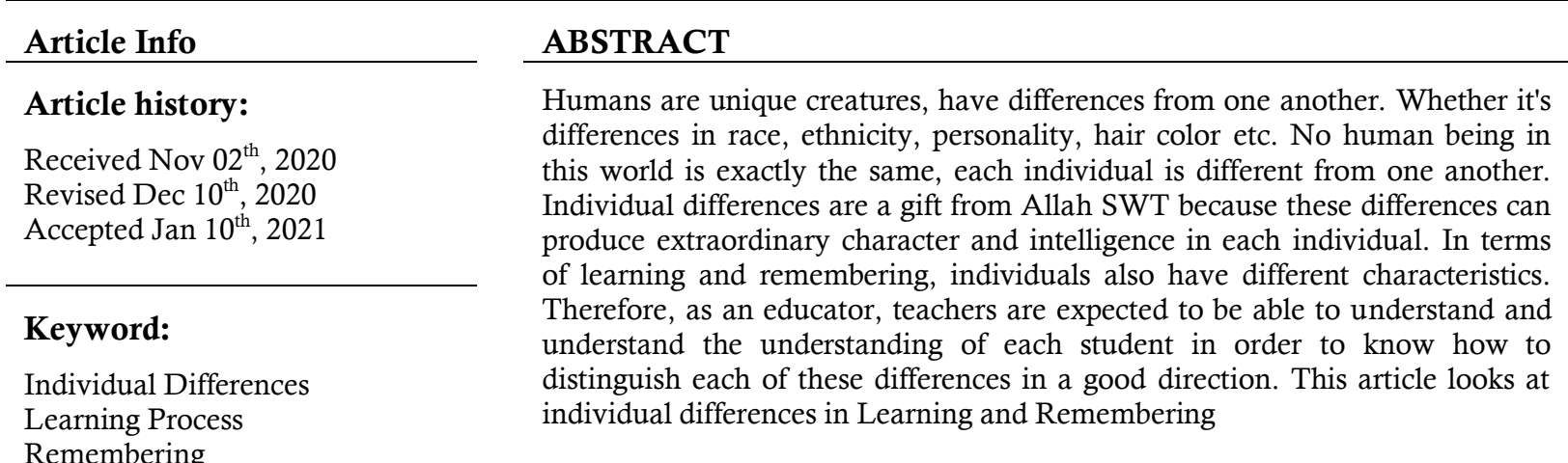

(C) 2021 The Authors. Published by IICET.

Remembering

\section{Corresponding Author:}

Elfi Churnia

Universitas Negeri Padang

Email: elfi@konselor.org

\section{Pendahuluan}

Manusia adalah makhluk yang unik (Anwar, 2006), memiliki perbedaan antara satu dan yang lainnya (Priansa, 2017). Baik itu perbedaan ras, suku bangsa, kepribadian, warna rambut dll. Tidak ada manusia di dunia ini yang sama persis, tiap individu berbeda antara satu dengan yang lainnya (Muchtar, Koswara, \& Setiaman, 2016). Perbedaan pada individu merupakan suatu karunia dari Allah SWT yang karena perbedaan tersebut dapat menghasilkan karakter dan kecerdasan luar biasa pada setiap individu. Dalam hal belajar dan mengingat, individu juga memiliki ciri khas yang berbeda (Rais, 2015). Oleh karena itu sebagai seorang pendidik, guru diharapkan mampu untuk mengenali dan memahami perbedaan pada setiap peserta didiknya agar tahu bagaimana cara untuk menangani setiap perbedaan tersebut ke arah yang baik.

Realitas dan gambaran perbedaan manusia memang benar-benar terjadi dan telihat dengan jelas. Setiap manusia pada umumnya memiliki perbedaan di dalam hal bagaimana cara belajar. Misalnya dalam kehidupan sehari-hari dapat kita lihat pada beberapa orang siswa di dalam kelas dalam mempelajari sebuah topik yang sama, ada siswa yang bekerja dengan menggunakan banyak catatan, ada yang mencatat metode, meringkas bacaan, dan sangat tergantung pada materi tertulis (Konadi, Mudjiran, \& Karneli, 2017). Selain itu, ada pula siswa yang tidak terlalu tergantung pada catatan, tetapi mereka banyak belajar melalui diskusi, dan berbicara tentang topik tersebut. Sementara yang lain belajar dengan mengingat fakta dengan menggambarkan materi pelajaran tersebut secara kompleks. Ini semua membuktikan bahwa manusia berbeda di dalam cara belajar, selain itu ada siswa yang cepat memahami materi pelajaran, dan ada juga yang lebih lambat (Neviyarni, Andriani, \& Ahmad, 2018). 


\section{Pembahasan}

\section{Hakekat Perbedaan Individu}

Menurut Ellis (1978: 144-145), pada abad kedua puluh ilmuwan telah umumnya terfokus pada satu aspek individualitas pada satu waktu dan berusaha untuk mengembangkan skala yang relatif terus menerus untuk mengukur sifat ini, bukan mengelompokkan orang secara keseluruhan ke dalam salah satu dari beberapa kelas. Fokusnya adalah pada karakteristik manusia yang cukup konsisten dari satu situasi ke depan, bukan pada ciri yang bersifat sementara dari individu tersebut (Ellis, 1978). Terdapat berbagai macam sifat-sifat seperti nilai, sikap, dan kepentingan sehubungan dengan mana orang berbeda.

Salah satu contoh perbedaan di dalam pembelajaran dan memori dapat dilihat pada dua orang anak yang berusia sama yang melakukan serangkaian tugas yang mengehendaki mereka mempelajari tugas tersebut untuk membedakan beberapa bentuk yang kelihatan serupa. Salah satu dari anak dapat melakukan tugas tersebut dengan mudah dan cepat, sementara yang lainnya membutuhkan waktu yang agak lama untuk mengerjakan tugas tersebut dengan mudah dan cepat, sementara yang lainnyamembutuhkan waktu yang agak lama untuk mengerjakan tugas tersebut.Begitu pula hasilnya, anak yang pertama mengerjakan dengan sempurna, sementara yang kedua membuahkan hasil yang kurang baik.dari kenyataan ini kita dapat menyimpulkan bahwa manusi mempunyai perbedaan di dalam hal bagai mana cara belajar.

Salah satu pendekatan yang sudah sangat terkenal untuk memahami perbedaan individual adalah dengan mengelompokkan orang berdasarkan tipe (Sugianto, Armanto, \& Harahap, 2014; Yuwono, 2010). Walaupun cara pengelompokkan ini tidak berdasarkan metode ilmiah, namun metode ini sudah banyak dikenal selama sejarah perkembangan ilmu psikologi (Sari, 2019). Metode kedua yaitu dengan mengembangkan sebuah skala untuk mengukur trait (ciri/kualitas) dan bukan mengelompokkan orang berdasarkan ciri tersebut diatas beberapa kelas. Fokus dari trait tersebut adalah ciri manusia yang konsisten dari satu situasi ke situasi berikutnya, dan bukan ciri yang bersifat sementara dari individu tersebut (Seniati, 2010).

\section{Sejarah Terdahulu}

Menurut Ellis (1978:145) Walaupun masalah perbedaan individual dalam pembelajaran dan memori kurang mendapat perhatian para ahli belajar, sejauh topik ini sudah berkembang sejak sebelum Masehi. Kira-kira 1000 sebelum Masehi. Cina sudah melakukan test bakat untuk mendapatkan calon orang yang menduduki jabatan pemerintah. Di Eropa, walaupun tidak menekankan pentingnya masalah perbedaan individu ini, pengukuran perbedaan individu pernah menjadi perhatian yang sangat besar pada sekitar 1700, pada saat perkembangan agama Protestan yang menekan perbedaan individu dan ilmu pengetahuan yang ditekankan pada pengukuran. Barangkali yang mendorong keterkaitan terhadap perbedaan individu pada saat itu adalah perkembangan teori evolusi yang diasosiasikan dengan prinsip keragaman (variation). Kenyataannya, pengukuran perbedaan di antara individu di dalam kerakteristik psikologis dihubungkan dengan Sir Francis Galton melakukan pengukuran "kemampuan intelektual" di Anthropometric Laboratory di London, dengan cara mengukur, kekuatan handgrib (gerakan tangan), test keterampilan motor, dan mengukur keakuratan visual dan audio (penglihatan dan pendengaran).

Tes intelegensi modern dikembangkan oleh Alfred Binet pada tahun 1904 atau permintaan ofisial sekolah Perancis. Binet dimana untuk membuat isntrumen untuk mengetahui anak-anak yang paling lemah di sekolah Paris. Secara umum test yang dibuat oleh Binet lebih kompleks dari yang dibuat oleh Gilton dan tidak terlalu menekankan pada karakteristik sensosri dan keterampilan motor. Ciri lain dari test Binet adalah bahwa respon yang diharapkan lebih praktis dan mengusahakan satu skor untuk mencermintkan intelegensi individu.

Menurut I Nyoman Surna guru yang setiap harinya berinteraksi dengan peserta didik, tentunya memiliki pengalaman yang sangat unik dari masing-masing peserta didik. Ada peserta didik yang memiliki kemampuan bernalar dengan baik yang ditunjukkan oleh kemampuannya berargumentasi dan menjawab pertanyaan secara runut dan mudah dipahami, ada peserta didik yang kurang mampu mengungkapkan pendapatnya dengan baik sekalipun sebenarnya peserta didik yang kurang mampu mengungkapkan pendapatnya dengan baik sekalipun sebenarnya peserta didik tersebut memahami isi dan makna persoalannya, serta ada pula yang sulit mengungkapkan pendapatnya. Dipihak lain, ada peserta didik yang memiliki cara belajar sambil mendengarkan radio atau mendengarkan lagu/music dan ada juga yang belajar sendiri, belajar kelompok, membuat catatan ringkasan dari hasil bacaan yang dipelajari, belajar dengan cara membaca keras, bahkan ada yang hanya diam saja sambil menyimak bahan bacaan ataupun bentuk-bentuk belajar lainnya sesuai dengan gaya belajar masing-masing (Surna \& Pandeirot, 2014).

Pada beberapa tahun belakangan banyak perhatian tercurahkan untuk mengkaji perbedaan individu dalam belajar dan mengingat, namun sebenarnya manusia telah mendiskusikan topik ini dalam waktu yang cukup 
lama. Dalam sejarahnya Kira-kira 1000 tahun sebelum masehi, Cina sudah melakukan tes bakat yang berbentuk tes panahan maupun aritmatika untuk mendapatkan calon orang yang akan menduduki jabatan pemerintahan. Di Eropa, pada sekitar 1700 tahun sebelum masehi, pada saat perkembangan agama Protestan, perbedaan individu dan ilmu pengetahuan ditekankan pada pengukuran. Yang menjadi pendorong ketertarikan terhadap perbedaan individu pada saat itu adalah perkembangan teori evolusi yang diasosiakan dengan prinsip keragaman. Kenyataannya, pengukuran perbedaan diantara individu dalam karakteristik psikologis dihubungkan dengan Sir Francis Galton, sepupu Darwin. Galton melakukan pengukuran "kemampuan intelektual" di Anthropometric Laboratory di London dengan cara mengukur, kekuatan cengkraman dan gerakan tangan (handgrip) tes keterampilan motor, dan mengukur keakuratan visual dan audio.

\section{Kajian Tentang Perbedaan Individu}

Menurut Ellis (1978:146-147) Beberapa metode penelitian yang dipergunakan dalam perkembangan kajian tentang perbedaan individu, sebagai berikut : (1) Dengan menggunakan statistik dan teknologi komputer. Para ahli psikologi tertarik untuk mendiskusikan perpaduan karakter individu yang dimulai dari pengukuran dan tes mental. Diharapkan tes ini akan konsisten dan reliable, mengukur suatu trait (ciri), danvaliddalam arti mendekati indikator kehidupan yang sebenarnya. Validitas dapat dilihat dengan melakukan pengukuran dua kali atau melakukan tes yang sedikit berbeda dengan interval yang pendek antara yang pertama dan kedua. Jika skor dari tes pertama sama dengan skor dari tes kedua, maka tes itu dapat dikatakan terpercaya (reliable). Jika tidak ada korelasi antara tes pertama dengan tes kedua, berarti ada sesuatu yang tidak beres, dan tes tersebut tidak reliable (2) Dengan menggunakan penelitian "long on data short on theory" (banyak data sedikit teori).Peneliti lebih banyak diarahkan pada masalah praktis dari pada teori di dalam investigasinya. Hasilnya lebih bersifat proliderasi tes mental yang mempunyai hubungan yang tidak jelas satu sama lain dengan ide teoritis (3) Dengan menggunakan penekanan yang terlalu bersifat kuantitatif. Fokus kuantifikasi merupakan hasil dari teknologi tes mental yang secara persis mencerminkan perbedaan penampilan individual dalam melakukan tugas tertentu. Beberapa kritik melihat bahwa kuantifikasi tersebut bersifat premature, belum matang, dan pendekatan ini belum melihat perbedaan intelegensi.

\section{Perbedaan Individu dalam Belajar dan Mengingat}

Terdapat beberapa perbedaan individu dalam belajar dan mengingat, diantaranya (dalam Ellis, 1978:147-150) yaitu:

\section{Intelegensi}

Menurut Herbert Spencer dalam Yusuf (2011), inteligensi adalah kemampuan bawaaan, atau kualitas bawaan sejak lahir sebagai hal yang berbeda dari kemampuan yang diperoleh melalui proses belajar. Sedangkan menurut Wechsler (dalam Wingkel, 1984), intelegensi adalah kemampuan bertindak dengan menetapkan suatu tujuan, untuk berfikir secara rasional, dan untuk berhubungan dengan lingkungan di sekitarnyaa secara memuaskan.

Pada tahun 1920, tes ini banyak digunakan di Amerika Serikat. Namun tes ini menimbulkan keraguan dalam kaitannya dengan apa yang diukur. Beberapa pakar melihat inteligensi tergambar dari kecepatan dan kemampuan belajar. Sementara pakar lain memandang inteligensi tercermin dari tingkat kesulitan masalah yang harus dipecahkan oleh seseorang pada tingkat usia tertentu.

\section{Gaya Kognitif}

Bakat individu dapat dipandang sebagai menunjukkan tingkat penampilan intelektual, sedangkan gaya kognitif mengacu pada cara penampilan atau bagaimana salah satu menyerang dan menantang tugas-tugas intelektual tersebut. Sebagai contoh, individu-individu berbeda dalam preferensi mereka, atau kemampuan untuk belajar bentuk, modalitas sensorik tertentu. Beberapa orang belajar terbaik dari bahan-bahan tertulis, sementara yang lain belajar lebih efisien dari pengolahan pendengaran konten yang sama.

Contoh lain dari variasi gaya kognitif terkait dengan penampilan refleksi atau impulsif. Perbedaan individu dalam hal ini dinilai dari tugas perseptual, mencocokkan sesuatu yang telah dikenal dengan bentuk yang sangat mirip dengan gambar target. Orang yang lebih lambat dari rata-rata dan yang membuat banyak kesalahan dari rata-rata digolongkan reflektif, sementara yang skornya diatas rata-rata di dalam kecepatan memberikan respon dan dalam jumlah kesalahan diklasifikasikan sebagai orang yang impulsive. 


\section{Strategi Belajar}

Dalam hal strategi belajar perbedaan individu lebih cenderung bersifat global yang mempengaruhi pembelajaran.hal ini sangat penting did alam menentukan penampilan seseorang dalam tugas tertentu dan dalam menentukan strategi yang digunakan dalam melakukan tugas tersebut.

Dalam belajar asosiasi berpasangan misalnya, strategi yang berbeda biasanya dibahas dalam rubrik mediasi atau teknik elaborasi. Salah satu dari dua metode yang biasanya digunakan untuk mempelajari perbedaan individu dalam konteks ini: subyek dalam eksperimen salah satu hanya tanya untuk strategi yang mereka gunakan atau diberikan instruksi yang eksplisit untuk menggunakan strategi khusus dan perbedaan dalam kemampuan mereka untuk menerapkan strategi yang mencatat. Dalam prosedur sebelumnya, strategi yang mungkin biasanya ditentukan oleh eksperimen sebelum awal percobaan dan peringkat menurut tingkat kompleksitas. Temuan dasar adalah bahwa subyek yang melaporkan rata-rata menggunakan strategi yang lebih kompleks cenderung berperforma lebih baik pada tugas asosiasi dipasangkan.

Perbedaan individu dalam strategi dalam mengingat bebas juga telah diteliti baru-baru ini. Dalam belajar verbal dan memori, Anda mungkin dapat mengantisipasi bahwa perbedaan penting antara subyek dalam jenis tugas berkaitan dengan kemampuan mereka untuk mengatur materi subyektif. Tidak hanya orang-orang yang subjektif mengatur materi di-recall bebas unggul untuk mereka yang tidak dalam hal jumlah kata ingat dalam tugas mengingat gratis, tetapi kinerja mereka juga unggul dalam belajar asosiasi dipasangkan, belajar serial, dan tugas pengakuan memori.

\section{Kemampuan Memori}

Individu tidak hanya berbeda dalam kemampuan mereka untuk memperoleh informasi, tetapi juga dalam kemampuan mereka untuk menyimpan dan mempertahankan informasi yang mereka dapatkan. Dalam beberapa tahun terakhir, psikolog telah mulai menyelidiki perbedaan-perbedaan dalam kemampuan memori dan menghubungkannya dengan inteligensi. Beberapa yang paling menarik dari pekerjaan ini telah dilakukan oleh istilah peneliti yang dipimpin oleh Earl Hunt, seorang psikolog eksperimental, dan Clifford Lunneborg, di sebuah psychometrician. Pada dasarnya, perbedaan tampaknya berada dalam jenis fungsi memori yang kemampuan ini terkait.

Pertama, kemampuan verbal tinggi biasanya menyiratkan efisiensi yang lebih besar dari memori jangka pendek. Tinggi dan rendah kemampuan kuantitatif subjek tidak berbeda dalam kecepatan mereka menjawab dalam tugas ini. Hal ini juga menunjukkan bahwa kemampuan verbal tinggi berkaitan dengan kecepatan lebih besar dari pengolahan informasi, terutama dalam situasi menekankan memori jangka pendek.

Kedua, kemampuan kuantitatif tinggi biasanya menyiratkan perlawanan yang lebih besar untuk melupakan yang disebabkan oleh gangguan.Dengan mengetahui kemampuan verbal seseorang,dapat memperkirakan tingkat belajar orang tersebut, sementara pengetahuan tentang kemampuan kuantitatif memungkinkan perkiraan retensi.

Hasil ini menarik karena tes kecerdasan dan tugas-tugas kognitif yang digunakan di sini sangat berbeda dalam tuntutan mereka pada subjek. Pada dasarnya, tes ini menyelidiki isi dari memori jangka panjang. Sebaliknya tugas kognitif, di mana subjek tinggi dan rendah-verbal yang berbeda, tergantung terutama pada tingkat pengolahan informasi dalam memori jangka pendek, bukan pada informasi tertentu yang disimpan dalam memori jangka panjang.

\section{Memori yang Baik}

Dalam kehidupan sehari-hari kita menemukan ada orang yang memiliki memori yang sangat baik yang dimiliki oleh individu sangat sedikit. Setidaknya dua orang tersebut telah banyak diamati oleh psikolog. Salah satunya, disebut sebagai VP, diuji pada pada tugas yang sudah dibicarakan terdahulu. Karya ini juga dilaporkan oleh Earl Hunt dan rekannya Tom Love. Yang kedua adalah S yang lebih dikenal dengan "menemonist" yang diteliti selama lebih dari dua puluh lima tahun oleh psikolog AR Rusia Luria. Hebatnya, baik VP dan S dibesarkan dalam daerah yang sama dari negara Eropa Timur yang sama.

VP dan S memiliki kemampuan memori yang luar biasa, namun mereka memperlihatkan cara yang berbeda. Misalnya mereka sama dalam mengingat angka, tapi yang satu lebih cepat dalam mengingat angka yang dibaca terbalik atau dari belakang. VP dilaporkan memiliki kemampuan imajinasi yang rendah dan gagal mengerjakan tes yang menghendaki pemanfaatan imajinasi.

Menurut Dalyono (2007:225-229) dalam proses belajar dikenal adanya bermacam-macam kegiatan yang memiliki corak yang berbeda antara satu dengan lainnya, baik dalam aspek materi dan metodenya mapun dalam aspek tujuan dan perubahan tingkah laku diharapkan. Keanekaragaman jenis belajar ini muncul dalam dunia pendidikan sejalan dengan kebutuhan kehidupan manusia yang juga bermacam-macam, yaitu: 


\section{Belajar abstrak}

Belajar abstrak ialah belajar yang menggunakan cara berpikir abstrak. Tujuannya adalah untuk memperoleh pemahaman dan pemecahan masalah-masalah yang tidak nyata.Dalam mempelajari hal-hal yang abstrak diperlukan peranan akal yang kuat di samping penguasaan atas prinsip, konsep, dan generalisasi.Termasuk dalam jenis ini misalnya belajar kosmografi, astronomi, dan juga bagian materi bidang studi agama seperti tauhid.

\section{Belajar keterampilan}

Belajar keterampilan adalah belajar dengan menggunakan gerak-gerakan motorik yakni berhubungan dengan urat-urat saraf dan otot-otot/Neeuromuscular.Tujuannya adalah memperoleh dan menguasai keterampilan jasmaniah tertentu.Dalam belajar jenis ini latihan-latihan intensif dan teratur amat diperlukan.Termasuk belajar dalam jenis ini misalnya belajar olahraga, music, menari, melukis, memperbaiki benda-benda elektronik, dan juga sebagai materi pelajaran agama, seperti ibadah shalat, dan haji.

\section{Belajar social}

Belajar sosial pada dasarnya adalah belajar memahami masalah-masalah dan teknik-teknik untuk memecahkan masalah tersebut. Tujuannya adalah untuk menguasai pemahaman dan kecakapan dalam memecahkan masalah-masalah sosial seperti: masalah keluarga, masalah persahabatan, masalah kelompok, dan masalah-masalah lain yang bersifat kemasyarakatan.

\section{Belajar pemecahan masalah}

Belajar pemecahan masalah pada dasarnya adalah belajar menggunakan metode-metode ilmiah atau berpikir secara sistematis, logis, teratur dan teliti.Tujuannya ialah untuk memperoleh kemampuan dan kecakapan kognitif untuk memecahkan masalah secara rasional, lugas, dan tuntas.

\section{Belajar rasional}

Belajar rasional ialah belajar dengan menggunakan kemampuan berpikir secara logis dan rasional (sesuai dengan akal sehat).Tujuannya ialah untuk memperoleh aneka ragam kecakapan menggunakan prinsip-prinsip dan konsep-konsep.Jenis belajar ini sangat erat kaitannya dengan belajar pemecahan masalah.

\section{Belajar kebiasaan}

Belajar kebiasaan adalah proses pembentukan kebiasaan-kebiasaan baru atau perbaikan kebiasaan-kebiasaan yang telah ada. Belajar kebiasaan, selain menggunakan perintah suri teladan dan pengalaman khusus, juga menggunakan hokum dan ganjaran.Tujuannya agar siswa memperolehsikap-sikap kebiasaan-kebiasaan perbuatan baru yang lebih tepat dan positif dalam arti selaras dengan kebutuhan ruang waktu (kontekstual).

\section{Belajar apresiasi}

Belajar apresiasi adalah belajar mempertimbangkan (judgment) arti penting atau nilai suatu objek.tujuannya adalah agar siswa memperoleh dan mengembangkan kecakapan ranah rasa (affective skills) yang dalam hal ini kemampuan menghargai secara tepat terhadap nilai objek tertentu misalnya apresiasi sastra, apresiasi music, dan sebagainya.

\section{Interaksi Atribut Perlakuan (Atribut by Treatment Interaction/ATI)}

Secara intuitif masuk akal bahwa dalam situasi pendidikan praktis pelajaran akan lebih baik ketika bekerja pada bahan yang karakteristiknya cocok dengan karakteristik pembelajar sendiri. Hal ini mendasari teori pembelajaran individu. Padahal sebenarnya pembelajar yang berbeda melakukan lebih efisien dalam kondisi yang berbeda, maka kita dapat mengatakan interaksi atribut-oleh-perawatan (ATI) ini dikatakan telah berlangsung.

ATI memiliki beberapa komponen, diantaranya (dalam Ellis, 1978:150-151) yaitu: 1) Atribut yang mengacu kepada perbedaan pengukuran individu si pelajar. 2) Treatment yang dapat diinterpretasikan ke alat, metoda dan program yang digunakan pengajaran atau kelas tradisional. 3) Interaction yakni elemen yang mempunyai makna statistic yang berkaitan dengan makna kata secara umum. Dalam hal ini, interaksi bermakna bahwa pengaruh perlakuan tertentu berbeda di dalam tipe pelajar yang berbeda, yang berarti pelajar mempunyai atribut yang berbeda.

Penelitian ATI ini kelihatan merupakan upaya menggabungkan dua disiplin yakni perbedaan individu dan psikologi eksperimental.Ahli perbedaan individual memperhatikan hanya atribut dan telah mengembangkan metodologi testing mental dan analisis faktor.Ahli psikologi eksperimental sebaliknya telah memandang perbedaan antara individu sebagai nuansa atau sebagai "variasi error" (error variance) yang harus dikurangi sedapat mungkin. 
Bidang lain penelitian ATI yang menerima banyak perhatian baru-baru ini berhubungan dengan interaksi antara strategi pembelajaran atau mediasi dengan kemampuan khusus tertentu. Salah satu pendekatan untuk masalah ini telah berusaha untuk mengisolasi tes yang akan menilai kemampuan yang diperlukan oleh strategi mediasi yang berbeda. Tes khusus yang digunakan biasanya telah diambil dari baterai tes yang dikembangkan oleh orang-orang seperti Thurstone dan Guilford untuk mengukur kemampuan intelektual tertentu.

Guildford mengemukakan bahwa bakat bertalian dengan kecakapan untuk melakukan sesuatu.Ia juga mengemukakan bahwa terdapat tiga dimensi yang terkandung dalam bakat, yaitu sebagai berikut: 1) Dimensi perseptual, yaitu kemampuan di dalam melakukan persepsi yang mencakup kepekaan indra, perhatian, orientasi ruang dan waktu serta kecepatan persepsi. 2) Dimensi psikomotor, mencakup kekuatan, impuls, kecepatan gerak, kecermatan dan kordinasi. 3) Dimensi intelektual, mencakup ingatan, pengenalan, berpikir dan evaluatif (Sunaryo, 2004).

\section{Kesimpulan}

Dalam hal belajar dan mengingat, individu memiliki ciri khas yang berbeda. Oleh karena itu sebagai seorang pendidik, guru diharapkan mampu untuk mengenali dan memahami perbedaan pada setiap peserta didiknya agar tahu bagaimana cara untuk menangani setiap perbedaan tersebut ke arah yang baik. Realitas dan gambaran perbedaan manusia memang benar-benar terjadi dan telihat dengan jelas. Setiap manusia pada umumnya memiliki perbedaan di dalam hal bagaimana cara belajar. Misalnya dalam kehidupan sehari-hari dapat kita lihat pada beberapa orang siswa di dalam kelas dalam mempelajari sebuah topik yang sama, ada siswa yang bekerja dengan menggunakan banyak catatan, ada yang mencatat metode, meringkas bacaan, dan sangat tergantung pada materi tertulis. Selain itu, ada pula siswa yang tidak terlalu tergantung pada catatan, tetapi mereka banyak belajar melalui diskusi, dan berbicara tentang topik tersebut. Sementara yang lain belajar dengan mengingat fakta dengan menggambarkan materi pelajaran tersebut secara kompleks. Ini semua membuktikan bahwa manusia berbeda di dalam cara belajar sama hal nya dengan mengingat.

\section{Referensi}

Anwar, S. (2006). Hakekat Manusia (Manusia Dimata Filosuf Dan Al-Qur'an Serta Kajian Tentang Inti Manusia). Jurnal Kajian Pendidikan Agama-Ta'lim Vol, 4(2-2006), 133.

Ellis, H. C. (1978). Fundamentals of human learning, memory, and cognition: Brown.

Konadi, H., Mudjiran, M., \& Karneli, Y. (2017). Efektivitas Pendekatan Rational Emotive Behavior Therapy melalui Bimbingan Kelompok untuk Mengatasi Stres Akademik Siswa. Konselor, 6(4), 120-131.

Muchtar, K., Koswara, I., \& Setiaman, A. (2016). Komunikasi antar budaya dalam perspektif antropologi. Jurnal Manajemen Komunikasi, 1(1).

Neviyarni, N., Andriani, I., \& Ahmad, R. (2018). Academic stress level guidance and counseling students at Universitas Negeri Padang. Konselor, 7(2), 55-62.

Priansa, D. J. (2017). Pengembangan Strategi Dan Model Pembelajaran: Inovatif, Kreatif, dan prestatif dalam memahami peserta didik.

Rais, M. (2015). Pengaruh penggunaan multimedia presentasi berbasis prezi dan gaya belajar terhadap kemampuan mengingat konsep. Jurnal MEKOM (Media Komunikasi Pendidikan Kejuruan), 2(1), 10-24.

Sari, P. S. M. (2019). Pengaruh Tipe Kepribadian A dan B Pada Kinerja Mahasiswa Akuntansi. E-Jurnal Akuntansi, 29(1), 50-63.

Seniati, L. (2010). Pengaruh masa kerja, trait kepribadian, kepuasan kerja, dan iklim psikologis terhadap komitmen dosen pada Universitas Indonesia. Hubs-Asia, 10(1).

Sugianto, S., Armanto, D., \& Harahap, M. B. (2014). Perbedaan Penerapan Model Pembelajaran Kooperatif Tipe Jigsaw dan STAD Ditinjau dari Kemampuan Penalaran dan Komunikasi Matematis Siswa SMA. Jurnal Didaktik Matematika, 1(1).

Sunaryo. (2004). Psikologi untuk Keperawatan. Jakarta: EGC.

Surna, I. N., \& Pandeirot, O. D. (2014). Psikologi Pendidikan 1. Jakarta: Erlangga.

Yuwono, A. (2010). Profil siswa sma dalam memecahkan Masalah matematika ditinjau Dari tipe kepribadian. UNS (Sebelas Maret University). 